Indonesian Journal of Biotechnology, June, 2015

Vol. 20, No. 1, pp.19-33

\title{
Application of Molecular Biology for Identification of Virus Resistance Gene in Melon
}

\author{
Budi Setiadi Daryono ${ }^{1 *}$ \\ ${ }^{1}$ Laboratory of Genetics and Breeding, Faculty of Biology, Universitas Gadjah Mada, \\ Yogyakarta, Indonesia.
}

\begin{abstract}
Source of resistance to an Indonesia isolate of Cucumber mosaic virus (CMV-B2) in melon cultivar Yamatouri has been reported. Moreover, Creb-2, a locus that confers resistance to CMV-B2 in Yamatouri has been determined as a single dominant gene. To elucidate the resistance mechanism conferred by $\mathrm{Creb}-2$ in more detail, it is necessary to clone the Creb-2 gene and determine its molecular structure. One approach is by amplification and cloning of melon resistance gene analogs (MRGAs) based on degenerated PCR primers designed from conserved amino acids in the NBS-LRR motifs (P-loop, Kinase-2, and the GLPL) and Toll/ Interleukin-1 receptor-like region (TIR). This study was aimed to identify and characterize the resistance gene analogs from Cucumis melo L. cv. Yamatouri by employing polymerase chain reactions (PCR) as a molecular biology tools with degenerate primers based on conserved motifs of cloned $R$ genes. The application of molecular biology such as DNA isolation, degenerate primers and PCR condition, cloning, sequencing, linkage analysis and mapping of resistance gene analogs to Creb-2 gene in melon will be widely discussed in this paper.
\end{abstract}

Keywords: resistance gene analogs, Cucumber mosaic virus, Cucumis melo L.

\section{Introduction}

Plant disease resistance is often controlled by Mendelian genes and follows a gene for gene relationship in many plant species and their pathogens (Dixon et al., 1996). According to this theory, there are many resistance $(R)$ genes in a plant species against each of its pathogens and there is corresponding a virulence gene in the pathogen population for every $R$ gene in the host plant. This theory has been well demonstrated in cases where plant resistance is associated with hypersensitivity. However, a clear cut resistance phenotype like hypersensitivity does not always exist in many other cases and plant resistance often shows both qualitative and quantitative components. The qualitative resistance

\footnotetext{
*Corresponding author:

Budi Setiadi Daryono

Laboratory of Genetics and Breeding, Faculty of Biology, Universitas Gadjah Mada, Yogyakarta 55281, Indonesia.

E-mail: bs_daryono@mail.ugm.ac.id
}

in many plant-pathogen relationships is hypersensitive, race specific, and governed by interactions between avirulence genes in pathogens and resistance genes in hosts, while the quantitative resistance is nonhypersensitive, presumably non-race specific, and controlled polygenes (Mindrinos et al., 1994).

Recent advances in DNA marker technology and genomic research have provided powerful tools for addressing many questions about genetics of interaction between plants and their pathogens. Large numbers of $R$ genes in several plant species have been accurately mapped to their corresponding genomic locations (Meyers et al., 1999). To date, at least $18 R$ genes including 17 dominant and 1 recessive one in nine plant species have been cloned (Bent et al., 1994). A general model of plant defense responses to pathogen invasion involving complex biochemical pathways has been proposed, explaining the molecular basis of the gene for gene theory (Dangl, 1998). 
The presence of conserved domains permitted grouping of $R$ genes into at least four classes and to propose their possible function in the defense response as part of signal transduction pathways (Backer et al., 1997). The first class of $R$ genes contains $P$ to, a serine-threonine protein kinase, which confers resistance to bacterial speck disease in tomato (Backer et al., 1997). The second class includes the $C f$ family of tomato $R$ genes, which are effective against leaf mold and encode putative trans-membrane receptors with extra cellularleucine-rich repeats (LRR) domains (Dixon et al., 1996; Jones et al., 1994; Timmerman-Vaughan et al., 2000). A kinase group, associated with a receptor domain results in a receptor-like kinase structure, characterizes the third class of genes, including Xa21, which confers resistance to rice bacterial blight (Shen et al., 1998). A nucleotide binding site (NBS) and a stretch of LRRs that characterize most of the functionally described $R$ genes make up the fourth class, examples of which are $N$ of tobacco, L6 of flax, and RPP5 and RPS2 of Arabidopsis spp. (Bent et al., 1994; Lander et al., 1987; Leister et al., 1998; Michelmore \& Meyer, 1998; Pan et al., 2000b; Thomphson et al., 1994). Lopez et al. (2003) reported that they also have been an NBS upstream domain, which is either a region contained coiled coils (CC) or a Toll/Interleukin-1 receptor-like region (TIR; so named because of its homology with the cytoplasmic domain of the corresponding proteins in Drosophilla spp. and mammals).

Based on sequence similarity between $R$ genes, a method using degenerate primers to target the conserved motifs has been successfully employed to isolate resistance gene analogs (RGAs) from potato (Lawrence et al., 1995), soybean (Joyeuk et al., 1999; Witham et al., 1994), rice (Leister et al., 1996), Arabidopsis spp. (Aatrs et al., 1998), lettuce (Saitou \& Nei, 1987), common bean (Geffroy et al., 1999; Leister et al., 1998; Pitrat \& Lecoq, 1980), melon (Brotman et al., 1998), and other monocotyledonous and dicotyledonous.
Source of resistance to CMV-B2 in melon cultivar Yamatouri has been reported (Daryono \& Natsuaki, 2002). Moreover, Creb-2, a locus that confers resistance to CMV-B2 in Yamatouri has been determined as a single dominant gene (Daryono et al., 2003). To elucidate the resistance mechanism conferred by $\mathrm{Creb}-2$ in more detail, it is necessary to clone the Creb-2 gene and determine its molecular structure. One approach is by amplification and cloning of melon resistance gene analogs (MRGAs) based on degenerated PCR primers designed from conserved amino acids in the NBS-LRR motifs (P-loop, Kinase-2, and the GLPL) and Toll/Interleukin-1 receptor-like region (TIR).

This study was aimed to identify and characterize the resistance gene analogs from Cucumis melo L. cv. Yamatouri by employing polymerase chain reaction (PCR) as a molecular biology tools with degenerate primers based on conserved motifs of cloned $R$ genes.

\section{Materials and Methods Plant materials}

Two melon cultivars, the resistant Yamatouri and the susceptible Vakharman were used for providing template DNA for PCR amplification of melon resistant gene analysis (MRGA). An $\mathrm{F}_{2}$ population consisting of 154 individual plants derived from a cross between Yamatouri and Vakharman was used for linkage analysis and mapping of MRGAs.

\section{Degenerate primers and PCR condition}

Primers (Table 1) were designed from the conservative motifs P-loop and GLPLAL of the NBS-LRR domain according to Leister et al. (1995) and Brotman et al. (1998). TIR was used by a set of primers TIR1 and TIR5 according to Lopez et al. (2003).

DNA was extracted and purified from leaf tissues according to the protocol of Nucleon Phytopure (Amersham International). PCR reactions were performed for both cultivars in a total volume $50 \mu 1$ reaction volumes in $600 \mu \mathrm{l}$ tubes. Each reaction mixture containing 
Table 1. Degenerate primers used to isolate resistance gene analogs in melon

\begin{tabular}{lcll}
\hline \multicolumn{1}{c}{ Protein region } & Primer & \multicolumn{1}{c}{ Sequence 5' $\rightarrow$ 3 $^{\prime}$} & \multicolumn{1}{c}{ Peptide encoded } \\
\hline Kinase-1 $(p$-loop $)$ & S2 & GGI GGR RTA GGI AAR ACI AC & GGVGKTT \\
& S2N & GGI GGI GTI GGI AAI ACI AC & GGVGKTT \\
$\begin{array}{lcll}\text { C-terminal conserved } \\
\text { domains }\end{array}$ & AS1 & AR IGC IAR IGG IAR ICC & GLPLAL \\
& AS1N & CAA CGC TAG TGG CAA TCC & GLPLAL \\
& AS3 & IAG IGC IAG IGG IAG ICC & GLPLAL \\
Kinase-3 & AS2 & YCT AGT TGT RAY DAT DAY YYT RC & (S/C)(R/K)(I/V) (I/M) \\
Kinase-2 & S10 & CCA IAC RTC RTC NAR NAC & VLDDVW \\
Toll/Interleukin-1 receptor & TIR1 & GAI GTN TTY TTI TCI TTY AGI GG & (D/E)VFLSF (R/ S)G \\
Toll/Interleukin-1 receptor & TIR5 & IGG GTC IAC GTC GTA GAA IAC IGG & PVFYDVDP \\
\hline
\end{tabular}

Abbreviations: $\mathrm{I}=$ Inosine; $\mathrm{R}=\mathrm{A} / \mathrm{G} ; \mathrm{N}=\mathrm{A} / \mathrm{C} / \mathrm{G} / \mathrm{T} ; \mathrm{Y}=\mathrm{C} / \mathrm{T} ; \mathrm{D}=\mathrm{A} / \mathrm{G} / \mathrm{T}$

$5 \mu 1$ of $10 X$ ExTaq buffer, $4 \mu 1$ of dNTPs , $0.5 \mu 1$ of ampliTaq ${ }^{\mathrm{TM}}$ (Takara, Japan), 25 picomoles of each primer and $10 \mathrm{ng}$ of genomic DNA. Amplification was performed on a DNA Thermal Cycler (PTM-100 ${ }^{\mathrm{TM}}$ Programmable Thermal Controller, MJ Research Inc.) with cycling conditions were initial denaturation at $95^{\circ} \mathrm{C}$ for 5 minutes followed by 35 cycles at $95^{\circ} \mathrm{C}$ for $1 \mathrm{~min}, 42-45^{\circ} \mathrm{C}$ for $1 \mathrm{~min}$, and $72^{\circ}$ $\mathrm{C}$ for $1.5 \mathrm{~min}$ and final extension step at $72^{\circ} \mathrm{C}$ for $10 \mathrm{~min}$ before holding at $4^{\circ} \mathrm{C}$.

\section{Cloning the PCR products}

PCR products were separated by electrophoresis in a 1\% agarose gel. Each expected band was eluted and purified with by the QIA Quick Gel Extraction Kit (QIAGEN, USA). PCR purified products were cloned into pGEM-T vector system (Promega Corp.) and transformed in Escherichia coli DH5a cells by electroporation, following GIBCO-BRL instruction. Approximately, 1020 clones derived from each expected band of parents were randomly picked. Plasmids were extracted using LaboPass ${ }^{\mathrm{TM}}$ Mini Plasmid DNA Purification Kit (LaboPass).

\section{Sequence analysis}

Clones from each clone were sequenced using the Dye Terminator Cycle Sequencing Kit and an Applied Biosystem Prism 377
DNA sequencer (Perkin-Elmer Applied Biosystems). Homology searchers were performed using the Genbank, EMBL, and DDBJ databases with the BLAST algorithm. Nucleotide and amino acid sequences were analyzed using MacVector 6.5 software (Oxford Molecular Ltd., USA). Comparisons between sequences were initially aligned using CLUSTAL W (Thomphson et al., 1994) with default parameters. Pair-wise sequence comparisons and alignments were conducted using multiple alignment parameters with a gap open penalty of 10 and a gap extension penalty of 5 for nucleotide analysis, and a gap open penalty of 10 and a gap extension penalty of 0.1 for amino acid analysis. Comparative sequences of members of the $R$ genes were obtained from Genbank under the following accession numbers: the tobacco $N$ gene (U51605); flax L6 (U27081); rice Pib (AB013448); Arabidopsis RPS2 (U12860) and RPS5 (AF180942), tomato Prf (U65391), and cowpea Cry (AB020487). To make consistent sequence comparisons, only the region between P-loop and GLPLAL motifs was used. The regions corresponding to the primers S2, S2N, AS1, AS2, AS3, 310, TIR1, and TRI5 were not included.

Using the neighbor-joining (NJ) algorithm according to Saitou and Nei (1987), phylogenetic analysis of the MRGAs based 
on NBS and TIR was performed to determine the relationship of these MRGAs with other members of the $R$ genes. The strength of the internal branches of the resulting tree was statistically tested by bootstrap analysis from 1,000 bootstrap replications.

\section{Restriction fragment length polymorphism (RFLP) analysis}

DNA samples from Yamatouri and Vakharman will be digested with five restriction enzymes (EcoRI, EcoRV, HindIII, Bam HI, and XbaI) according to the manufacture's instruction (Amersham Pharmacia Biotech). Ten $\mu \mathrm{g}$ of the digested DNA is separated on $1 \%$ agarose gel. DNA fragments are blotted on a Hybond $\mathrm{N}^{+}$membrane (Amersham Pharmacia Biotech) according to the manufacture's instruction. Digoxygenin-labeled probes are prepare using a PCR DIG Labeling Mix (Boehringer Mannheim, Germany) and use for hybridization to melon DNA according to the manufacture's instruction. After overnight hybridization at $65^{\circ} \mathrm{C}$, the membrane is washed once in a solution of 2X SSC (1X SSC is $0.15 \mathrm{M} \mathrm{NaCl}$ plus $0.015 \mathrm{M}$ sodium citrate) and $0.1 \%$ sodium dodecyl sulfate (SDS) for 10 minutes, at $65^{\circ} \mathrm{C}$, then in 1X SSC and $0.1 \%$ SDS for 20 minutes at $65^{\circ} \mathrm{C}$. The hybridization signal will be detected by exposure to X-ray films according to the manufacturer's instruction.

\section{Linkage analysis}

RFLP segregation will be evaluated in the $\mathrm{F}_{2}$ population consisting of 154 individual plants derived from a cross between Yamatouri and Vakharman. Developed MRGA markers will be used for linkage mapping in 154 $\mathrm{F}_{2}$ individual plants. Linkage analysis is performed using the MAPMAKER/EXP 3.0 software originally described by Lander et al. (1987).

\section{Results}

Cloning and sequence analysis of melon resistance gene analogs

To isolate melon resistance gene analogs (MRGAs), six combinations of degenerate primers (Table 2), were used on genomic DNA of cultivar Yamatouri. Although some amplification showed multiple band patterns, only fragments of the expected size (Table 2) were cloned. However, sequencing from the combination VI (MRGAs 12 to 15) revealed that they were not homologous with $R$ genes and not used for further study.

Using primer combination I, several PCR products were obtained and ranging from 510 to $2300 \mathrm{bp}$ (Figure 1). Primer combination II generated a single major product approximately $300 \mathrm{bp}$ (Figure 1). Using primer combination III, a single major product of about $250 \mathrm{bp}$ was detected (Figure1). Primer combination IV generated several PCR products ranging from 350 to $800 \mathrm{bp}$, and using primer combination $\mathrm{V}$, three PCR products were obtained and ranging from 300 to $1200 \mathrm{bp}$ (Figure 1). The $510 \mathrm{bp}$ (I-510 and IV-510), $300 \mathrm{bp}$, and $250 \mathrm{bp}$ products which had the mobility expected from the NBS sequences in $N$, L6, Prf, Pib, Cry, and RPS2 protein, were cloned and approximately 50-70 clones were sequenced. Clones from combination I and IV were groped in three classes of MRGAs (MRGA1, MRGA2, and MRGA3), while from

Table 2. Primer combinations used in this study to isolate resistance gene analogs in melon

\begin{tabular}{ccccl}
\hline Combination & Primers & Tm & Expected size (bp) & Product clone \\
\hline I & S2 + AS1 & 45 & $500-600$ & MRGAs 1- 2 \\
II & S2 + AS2 & 45 & 300 & MRGAs 4 - 7 \\
III & S2 + 310 & 42 & $230-270$ & MRGAs 8 - 9 \\
IV & S2N + AS3 & 45 & 500 & MRGAs 3 \\
V & TIR1 + TIR5 & 42 & 300 & MRGAs 10 - 11 \\
VI & S2N + AS1N & 45 & $500-600$ & MRGAs 12-15* \\
\hline
\end{tabular}

* Not homologues to other $R$-genes 
combination II were grouped in four classes of MRGAs (MRGA4, MRGA5, MRGA6, and MRGA7), and from combination III were grouped in two classes of MRGAs (MRGA8, and MRGA9; Table 2). On the other hand, clones from combination $\mathrm{V}$ were grouped in two classes of MRGAs (MRGA10 and MRGA11 (Table 2).

Different MRGAs were classified by pair-wise comparisons of their deduced amino acid sequences and those of the NBS of known $R$ genes (Table 3 ). Identities between classes were equivalent to those between different $R$ genes, although this was not the case for pairs MRGA4-MRGA5 and MRGA6MRGA7, which were very similar but not identical (Table 3).

The melon NBS sequences exhibit high sequences divergent and the most closely related sequences are MRGA4, MRGA5, MRGA6, and MRGA7 (47-59\% deduced amino acid identity), while homology between other MRGAs is low e.g. MRGA1 and MRGA9 (6\% identity); MRGA2 and MRGA6 (14\% identity). Furthermore, amino acid sequence comparison with NBS of known $R$ genes revealed that MRGAs had 9 to $27 \%$ identities with the tobacco $N$ gene, 10 to $28 \%$ identities with the flax L6 gene, 10 to $17 \%$ identities with the

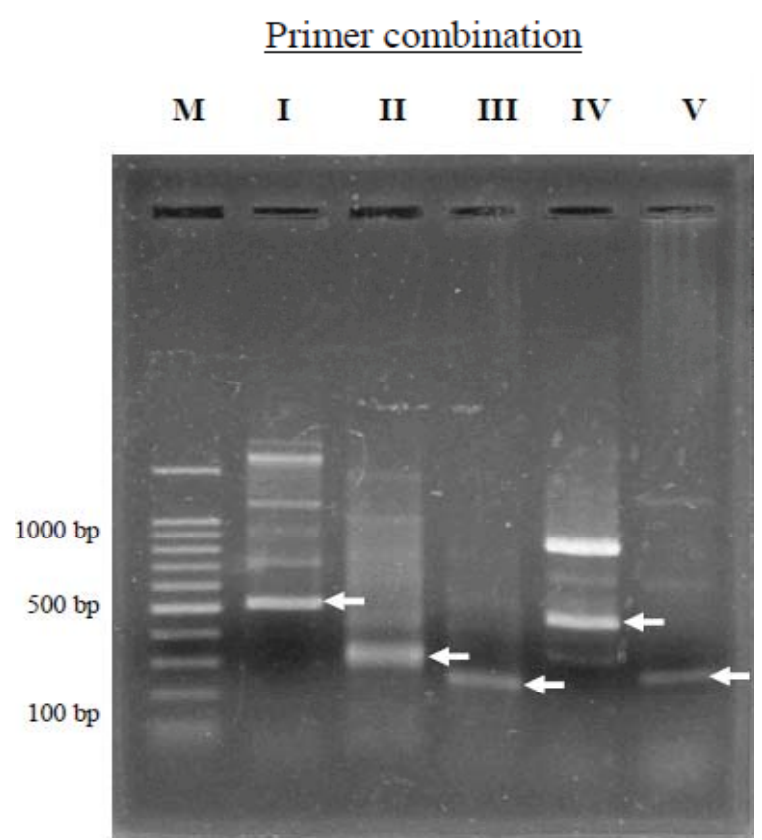

Figure1. Amplification of nucleotides-binding site and leucine-rich repeats (NBS-LRR) and Toll/Interleukin-1 receptor (TIR) sequences of melon. I:S2 and AS1; II: S2 and AS2; III: S2 and 310; IV:S2N and AS3; V: TIR1 and TIR5. M: 100 bp DNA ladder (Promega). Arrows indicate DNA bands showing expected mobility.

tomato Prf gene, 8 to $18 \%$ identities with rice Pib, 11 to $31 \%$ identities with cowpea Cry, and 10 to $14 \%$ identities with RPS2 of Arabidopsis spp. (Table 3).

Table 3. Comparison of nucleotide binding site-type melon resistance gene analogs (MRGAs) from melon with cloned resistance genes ${ }^{\mathrm{a}}$

\begin{tabular}{|c|c|c|c|c|c|c|c|c|c|c|c|c|c|c|}
\hline \multirow{2}{*}{ MRGA } & \multicolumn{14}{|c|}{ MRGA } \\
\hline & 2 & 3 & 4 & 5 & 6 & 7 & 8 & 9 & $\mathrm{~N}$ & L6 & Prf & Pib & Cry & RPS2 \\
\hline 1 & 13 & 14 & 7 & 9 & 8 & 10 & 8 & 6 & 15 & 14 & 15 & 10 & 14 & 16 \\
\hline 2 & & 24 & 13 & 10 & 14 & 13 & 7 & 10 & 17 & 19 & 17 & 18 & 19 & 15 \\
\hline 3 & & & 6 & 7 & 12 & 6 & 7 & 7 & 14 & 14 & 15 & 17 & 16 & 13 \\
\hline 4 & & & & 59 & 47 & 47 & 14 & 19 & 21 & 23 & 13 & 13 & 25 & 14 \\
\hline 5 & & & & & 44 & 61 & 14 & 16 & 22 & 21 & 13 & 12 & 22 & 14 \\
\hline 6 & & & & & & 47 & 18 & 19 & 27 & 28 & 17 & 15 & 31 & 14 \\
\hline 7 & & & & & & & 16 & 14 & 23 & 22 & 13 & 12 & 23 & 14 \\
\hline 8 & & & & & & & & 27 & 12 & 10 & 10 & 8 & 11 & 10 \\
\hline 9 & & & & & & & & & 9 & 10 & 11 & 9 & 12 & 14 \\
\hline $\mathrm{N}$ & & & & & & & & & & 35 & 21 & 18 & 42 & 25 \\
\hline L6 & & & & & & & & & & & 19 & 19 & 37 & 20 \\
\hline Prf & & & & & & & & & & & & 27 & 20 & 19 \\
\hline Pib & & & & & & & & & & & & & 25 & 17 \\
\hline Cry & & & & & & & & & & & & & & 25 \\
\hline
\end{tabular}

a Values correspond to the percent identity of the deduced amino acid sequences. 
Daryono

Table 4. Comparison of Toll/Interleukin-1 receptor (TIR)-type resistance gene analogs (RGAs) from melon with cloned resistance genes ${ }^{\mathrm{a}}$

\begin{tabular}{ccccc}
\hline MRGA & MRGA11 & TIR-N & TIR-L6 & TIR-RPS5 \\
\hline MRGA10 & 41 & 55 & 44 & 53 \\
MRGA11 & & 31 & 33 & 34 \\
TIR-N & & & 44 & 57 \\
TIR-L6 & & & & 38 \\
\hline
\end{tabular}

${ }^{a}$ Values correspond to the percent identity of the deduced amino acid sequences.

The expected $300 \mathrm{bp}$ band was cloned from combination $\mathrm{V}$, which targeted the TIR domain of $R$ genes. Deduced amino sequences of TIR-type MRGAs were compared and assembled in two classes (MRGA10 and MRGA11; Table 4). These MRGAs also showed an internal conserved motif (TIR-2; as reported by Meyer et al., 1999) of $R$ genes (Figure 3). Identities between TIR-type MRGAs and the TIR domain of $R$ genes are higher than in the case of the NBS (Table 4). MRGAs had 31 to $55 \%$ identities with the tobacco TIR-N gene; 33-44\% identities with the flax TIR-L6 gene; and 34-57\% identities with TIR-RPS5 of Arabidopsis spp.
I.J. Biotech.

According to the amino acid sequences predicted from MRGA nucleotide sequences, MRGAs 1 to 3 contained the kinase 2 and kinase 3 with C-terminal conserved domains which function in binding with phosphate groups of nucleotides and with bases or sugars, respectively. Whereas, MRGAs 4 to 7 encompassing a p-loop to kinase 3 . On the other hand, MRGAs 8 and 9 contained a p-loop and the kinase 2 (Figure 2). Furthermore, MRGAs 10 and 11 encompassing a TIR-1 to TIR-5 and also showed an internal conserved motif (TIR2, Figure 3).

The dendrogram (Figure 4) divides the sequence into two broad subfamilies on NBS type: the first, rather-tight cluster includes five melon gene fragments (MRGA1, MRGA2, MRGA3, MRGA8, and MRGA9) as well as the RPS2 Arabidopsis, the rice Pib, and the tomato Prf. The second much loser cluster comprises four melon gene fragments (MRGA4, MRGA5, MRGA6, and MRGA7) and three NBS (the tobacco $N$ gene, flax $L 6$ gene, and the cowpea Cry; and Arabidopsis RPS2). Similarly, in TIR type (Figure 5), the dendrogram divides the sequence into two subfamilies on TIR type;

Table 5. Nucleotides sequence of MRGAs primers used in Yamatouri and Vakharman

\begin{tabular}{|c|c|c|c|}
\hline $\begin{array}{c}\text { Primer } \\
\text { name }\end{array}$ & $\begin{array}{c}\text { Sequence } \\
5^{\prime}-3^{\prime}\end{array}$ & $\mathrm{TM}$ & $\begin{array}{l}\text { Size } \\
(\mathrm{bp})\end{array}$ \\
\hline MRGA-1F & TCGGCACAGCCGTTGGTGTCG & 48 & 534 \\
\hline MRGA-1R & CGCTCCTGTAGTATCTACGAC & & \\
\hline MRGA-2F & СТTAACAATATCTAAAAATATAGG & 50 & 507 \\
\hline MRGA-2R & GGCGAGGGGCAAGAAGGATGCGTG & & \\
\hline MRGA-3F & TGGCTACTCAAAAAGGCCTTGG & 52 & 498 \\
\hline MRGA-3R & ATCGAGAGGTAGGAAGGATGCG & & \\
\hline MRGA-4F & ATTGCTGAAGCTTGTTACAAC & 48 & 333 \\
\hline MRGA-4R & CCTGCTTCCGGGTGCAAACCA & & \\
\hline MRGA-7F & TGACTATACCCTTTCACGACC & 50 & 333 \\
\hline MRGA-7R & TACTTCCGCGTCCGCGGGATT & & \\
\hline MRGA-8F & GGCAAAGACAATCTTCCATCACG & 53 & 240 \\
\hline MRGA-8R & АTATCTTTTACСТCGCATCACCT & & \\
\hline MRGA-9F & GTTGAAGAAATTGCAAGATTGGC & 53 & 240 \\
\hline MRGA-9R & САССТТСТТСТСАТСТСТААССТ & & \\
\hline MRGA-10F & GGGAGAGGATACTCGAGACAAG & 53 & 294 \\
\hline MRGA-10R & AACTCTTTGTTTCTTCGATCTC & & \\
\hline MRGA-11F & CGATCTCATGACACTCTAATTA & 53 & 294 \\
\hline MRGA-11R & GTTTCTTTGTCGTTCAGGGGAG & & \\
\hline
\end{tabular}




Consensus
MRGA1
MRGA2
MRGA3
NBS-RPS2
NBS-Prf
NBS-Pib
NBS-N
NBS-L6
Cry
MRGA4
MRGA5
MRGA6
MRGA7
MRGA8
MRGA9

Consensus MRGA1 MRGA2 MRGA3 NBS-RPS2 NBS-Prf NBS-Pib NBS-N NBS-L6 Cry MRGA4 MRGA5 MRGA6 MRGA7 MRGA8 MRGA9

Consensus MRGA1 MRGA2 MRGA3 NBS-RPS2 NBS-Prf NBS-Pib NBS-N NBS-L6 Cry MRGA4 MRGA5 MRGA6 MRGA7 MRGA8 MRGA9

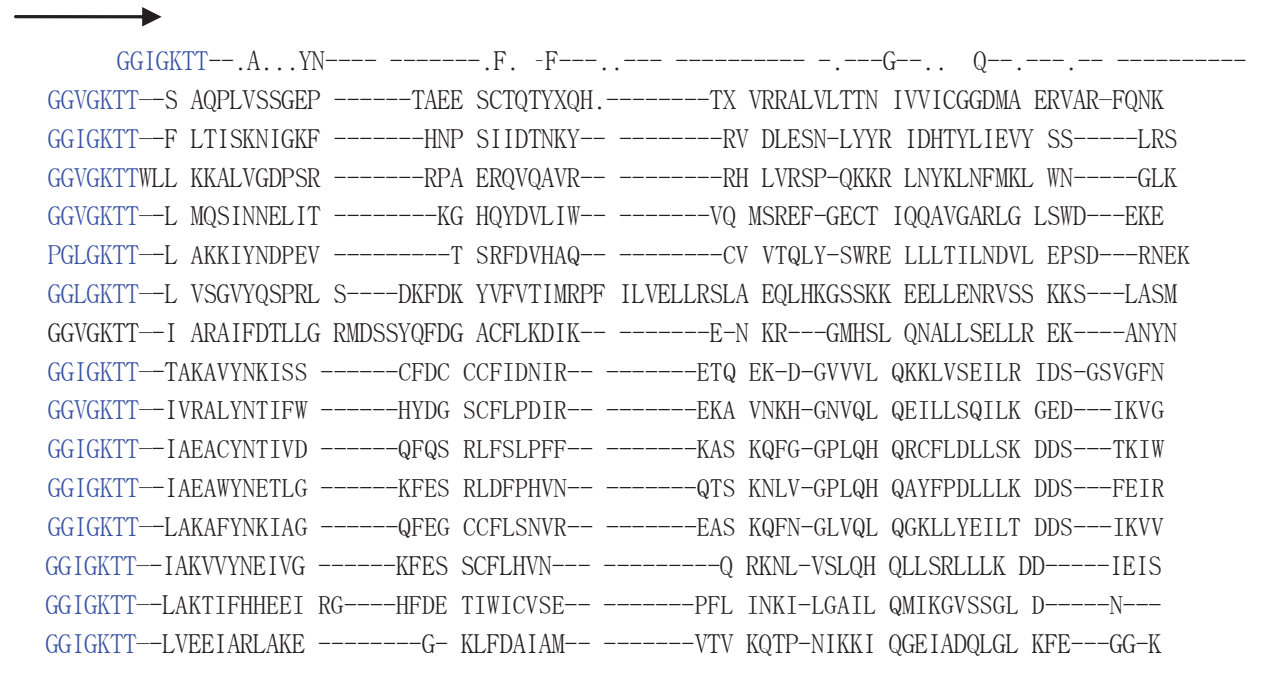

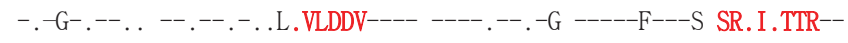

SAARIERRTG RAARXAGDVI LRYLDI SEAI PEWSIPTSSG VPANDTSRVS LPVDVSYVNV AMRVWLARPG ALSTDVARTR LSGLSRGHYG LLILDR-KVL IVLDDWLRFI NNY-LKYHKS SFGPYFKSRS SELQDTVHKI IKIKPPIKCS NQGLHGIVKR KIEIVTTQLS GLSXGHYSVLRLNHKTQKLI KDW-LRFIKN VR-NITKAVSG GENRALKIYR ALRQKR--FL LLLDDVWEEI -DL-EKTGVP RP-DRENK-CK EDGEIADELR RFLLTK-RFLILIDDVWDYK -VW-D-NLCM CF-SDVSNRS EDTELTGQLKRLLEKKK-SCLIVLDDFSDTS-EW-DQIKPTLF-PLLEKT NEEDGKHQMASRLRSKKVLILVLDDIDNKD-HYLEYLAGDL-DWFGNGSR NDSGGRKTIKERVSRF-KILVVLDVDEK-FK-LEYLAGDL-DWFGNGSR DVNRGIPLIKRRLQQK-KVLLVLDVDKL-EQ-LKALAGGC-DWFGSGSI DEDHGAQMIK HHMSNR-KVL IVLDGVDER- NQ-IEKLVGS P-TWFAPGSR DEDRGAQMIE NEMISR-MAL VGLDDIDEK- RQ-VEVLVGS P-TWFAPGSR NIDRGVNIIR NRLCSK-KVL IVLDDVDSR- GR-LQVLVGE L-HWFGRGSR NEDRGAQMIE NEMKSR-MAL VVLDDIDRK- GR-LKVLVGS P-DWFGHGSR -KEALLRELQ KVMRGK-RYF LVLDDVPILNHSHESF KYNTK---- -IIKLKSHKT KVMFTTRSIA LCNNMG--AE YKLRVEFLEK IILTTRLNDV AEYVKCESDP HHLRLFRDD SRI IVTTRKENIANHCSGKNGNVHNLKVLK IIITTRDKHL IEKND-----I IYEVTALPDH II ITTRDKHLIEKND-----I IYEVTALPDH IIITTRDKHLLDARG-VVNLYEVKPLKVE VIITTVIITTR---- --_--_---_- -----_--_-- 160 VFATTR---- --_-_--_-- --_--_--_-- 160 VFITTR---- ----------- ----------- $\quad 160$ 160

80 80 80 80 80 80 80 80 80 80 80 80 80 80 80 80

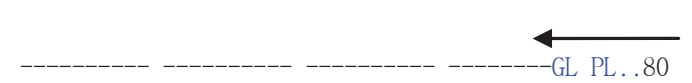

RPKRHEGPSS GYIFVVSET- -------DRS AIVVDTTGGL PLAL80

KEKLINTSAE AKGNQTRP-- -------YGL HASFLPLAGL PLAL80

KYSNKIYQRK HKENQTHP-- -------YCL HASFLPLDGL PLAL80

KHAWELFCSK VWRKDLLES- ---SSIRRLA EIIVSKCGGL PLAL80

E-SWTLLQKE VFQGESCP-- ---PELEDVG FEISKSCRGL PLSV80

NDALCLLSEK VFEEATYLDD QNNPELVKEA KQILKKCDGL PLAI80

HESIQLFKQH AFGKEVPNE- ---N-FEKLS LEVVNYAKGL PLAL80

PRSLELFSKH AFKKNTPPS- ---Y-YETLA NDVVDTTAGL PLTL80

ERALELFSWH AFKNGKVDP- ---P-YMKIA MRAVSYACGL PFA-80

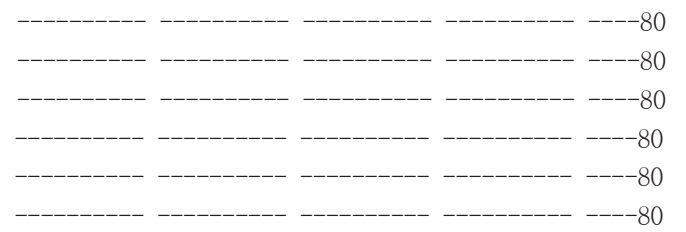

Figure 2. Alignment of the putative amino acid sequences of nine melon resistance gene analogs (MRGA) with those of the resistance genes $N$ (tobacco), L6 (flax), Prf (tomato), Pib (rice), Cry (cowpea), and RPS2 (Arabidopsis spp.) using CLUSTAL W. Kinase 2 and 3 domains are indicated in bold. Arrows indicate position and direction of PCR primers used for amplification of melon NBS-LRR sequences. 
Consensus EVFLSFRG-DTR-F.SHL...LRGK-I.TF-DD-L.RG.-I---L.KAI .---ES.-ISI 60

MRGA10 EVFLSFRGED TRDKFISHL VVALRQKGVN FFIDDK-LDR GHQISKSLLK SIE-ESRISI 60

MRGA11 EVFLSFRSHD TLIIFISHL VQTPRGRCII LGENND---R NPRLLYRFEK GFRNLVTPISL 60

TIR-RPS5 DVFPSFSGVDVRKTFLSHL LKALDGKSIN TFIDHG-IER SRTIAPELIS AIR--EARISI 60

TIR-N DVFLSFRGED TRKTFTSHL YEVLNGKGIK TFQDDKRLEY GATIPGELCK AIE--ESQFAI 60

TIR-L6 EVFLSFRGPD TREQFTDFL YQSLRRYKIH TFRDDDELLK GKEIGPNLLR AID--SKIYV 60

\section{TIR-1}

Consensus VIFS. NYA. S TWCL-EL-EI. ${ }^{-}$- $^{----}$. Q-VLPVFYDVD P 101

MRGA10 IIFSQNYASS TWCLDELGEN NLSVMRSKKQ RVLPVFYDVD P 101

MRGA11 VIYEEIYALS TWCHDKIDEI VSSILSPERQ RNLPVFYDVD P 101

TIR-RPS5 VIFSKNYASS TWCLNELVEI HKCFNDLG-Q MVIPVFYDVD P 101

TIR-N VVFSENYATS RWCLNELVKI MECKTRFK-Q TVIPIFYDVD P 101

TIR-L6 PIISSGYADS KWCLMELAEI VRRQEEDPRR IILPIFYMVD P 101

Figure 3. Alignment of the putative amino acid sequences of the Toll/Interleukin-1 receptor (TIR)-type resistance gene analogs (RGAs) with the TIR domain of $N$ (tobacco), L6 (flax), and RPS5 (Arabidopsis spp.). Amino acids in the conserved motifs TIR-1 and TIR-5 are shown in the bold, while TIR-2 is shown in blue color.

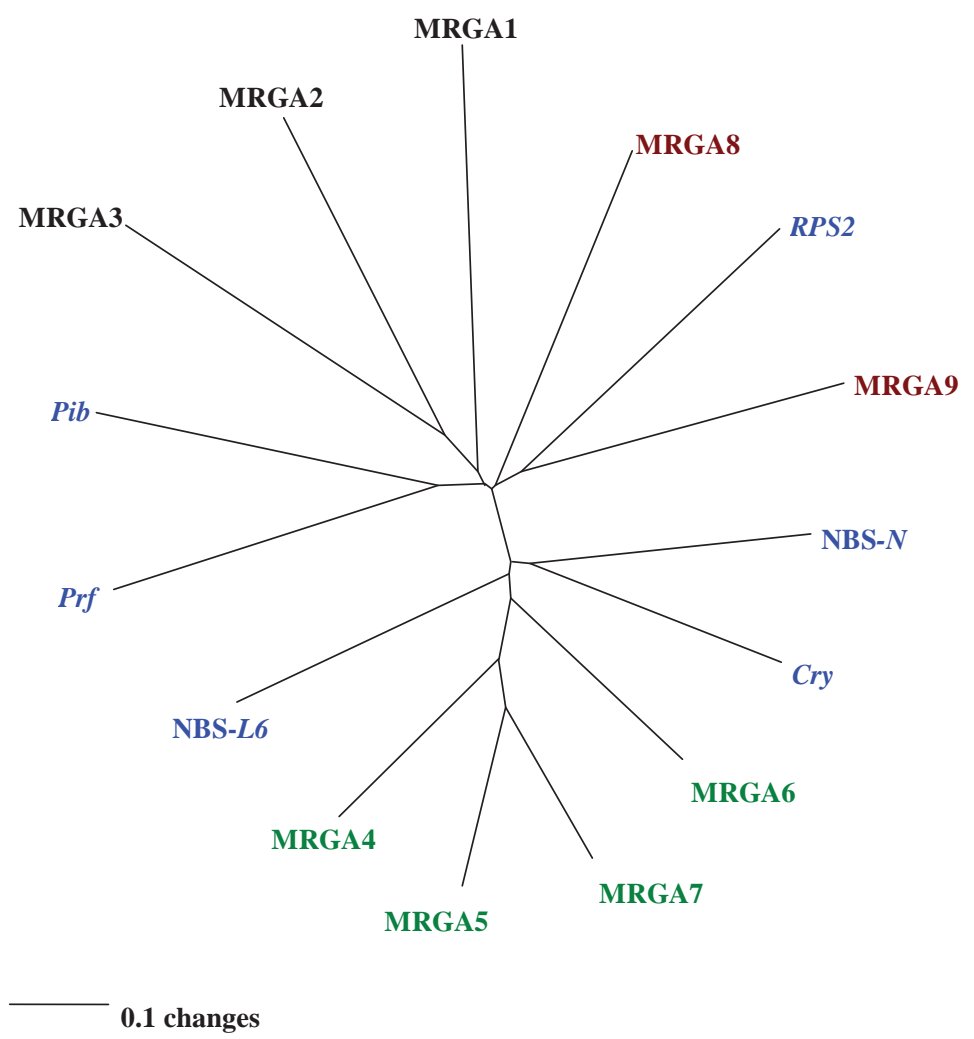

Figure 4.Dendrogram of nucleotide binding sequences (NBS) genomic fragments from melon and from representative Rgenes of other plants. Non melon sequence included the tobacco $N$ gene (U51605); flax L6 (U27081); rice Pib (AB013448); Arabidopsis RPS2 (U12860), tomato Prf (U65391), and cowpea Cry (AB020487). 


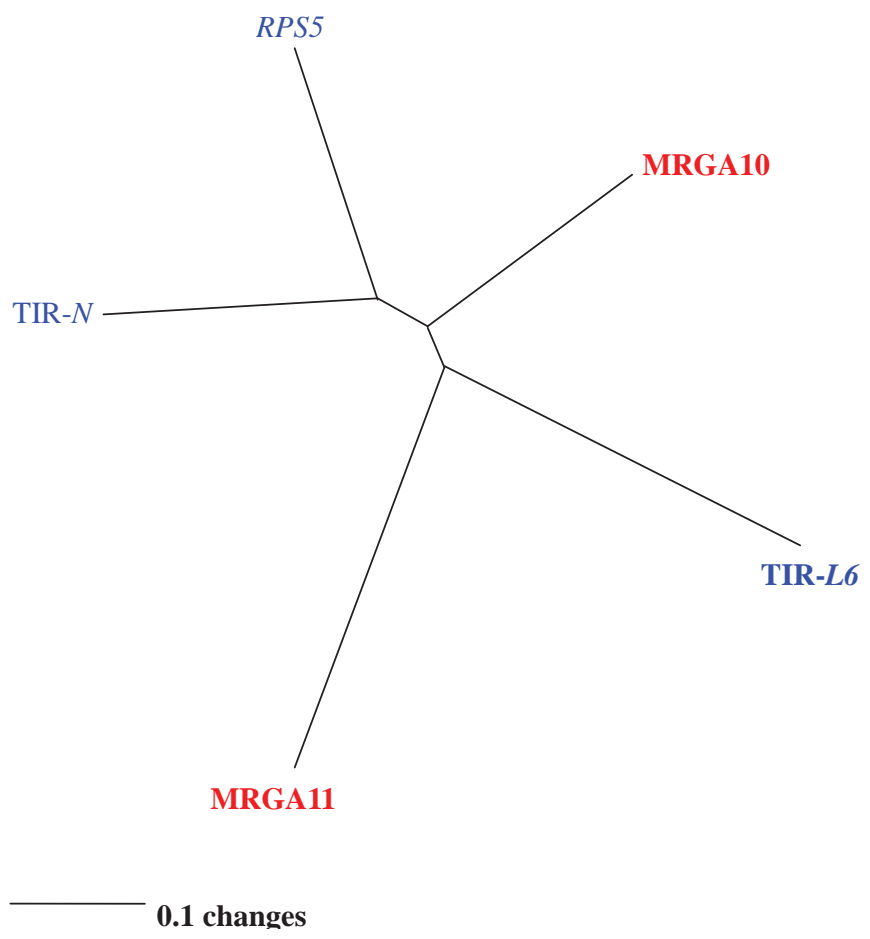

Figure 5. Dendrogram of the Toll/Interleukin-1 receptor (TIR) genomic fragments from melon and from representative Rgenes of other plants. Non melon sequence included the tobacco N gene (U51605); flax L6 (U27081); tomato Prf (U65391); and Arabidopsis RPS5 (AF180942).

first cluster includes MRGA10, MRGA11, and the flax TIR-L6 gene, while the second cluster includes the tobacco TIR-N gene and the TIRRPS5 gene of Arabidopsis spp.

\section{Application of MRGAs primers in Yamatouri and Vakharman}

Based on nucleotides sequence results of MRGAs, some MRGAs primers were designed to detect polymorphism of resistance gene analogues (RGAs) in Yamatouri and Vakharman (Tabel 5). Among nine MRGAs primers, only MRGA-1 primers showed RGA polymorphism between Yamatouri and Vakharman in 534 bp (Figure 6), while other MRGAs primers failed obtained RGA polymorphism.

\section{Southern-blot analysis}

The 534 bp amplified by MRGA1 primers was then used as probe in Southernblot analysis. To investigate the genomic distribution of MRGAs in melon, genomic
Southern-blot analysis was applied. MRGAs-1 clone was selected and used as a probe against DNAs of the resistant Yamatouri and susceptible Vakharman digested with five restriction endonucleases (EcoRI, EcoRV, HindIII, XbaI, and BamIII). A polymorphism between Yamatouri and Vakharman was detected when MRGAs1 was used as a probe; a single major band was present in lanes of Yamatouri DNA digested with EcoRI, EcoRV, and $\mathrm{XbaI}$, whereas weak hybridization signals with different mobility were detected in corresponding lanes of Vakharman DNA (Figure7). In contrast, MRGA-1 showed copious hybridizing bands both in Yamatouri and Vakharman digested with HindIII and BamIII respectively (Figure 7).

\section{Linkage analysis and mapping of MRGA with the Creb-2 locus}

The linkage of MRGA1 with the Creb-2 resistancelocus wasinvestigated. RFLP marker MRGA1 was converted into sequenced- 


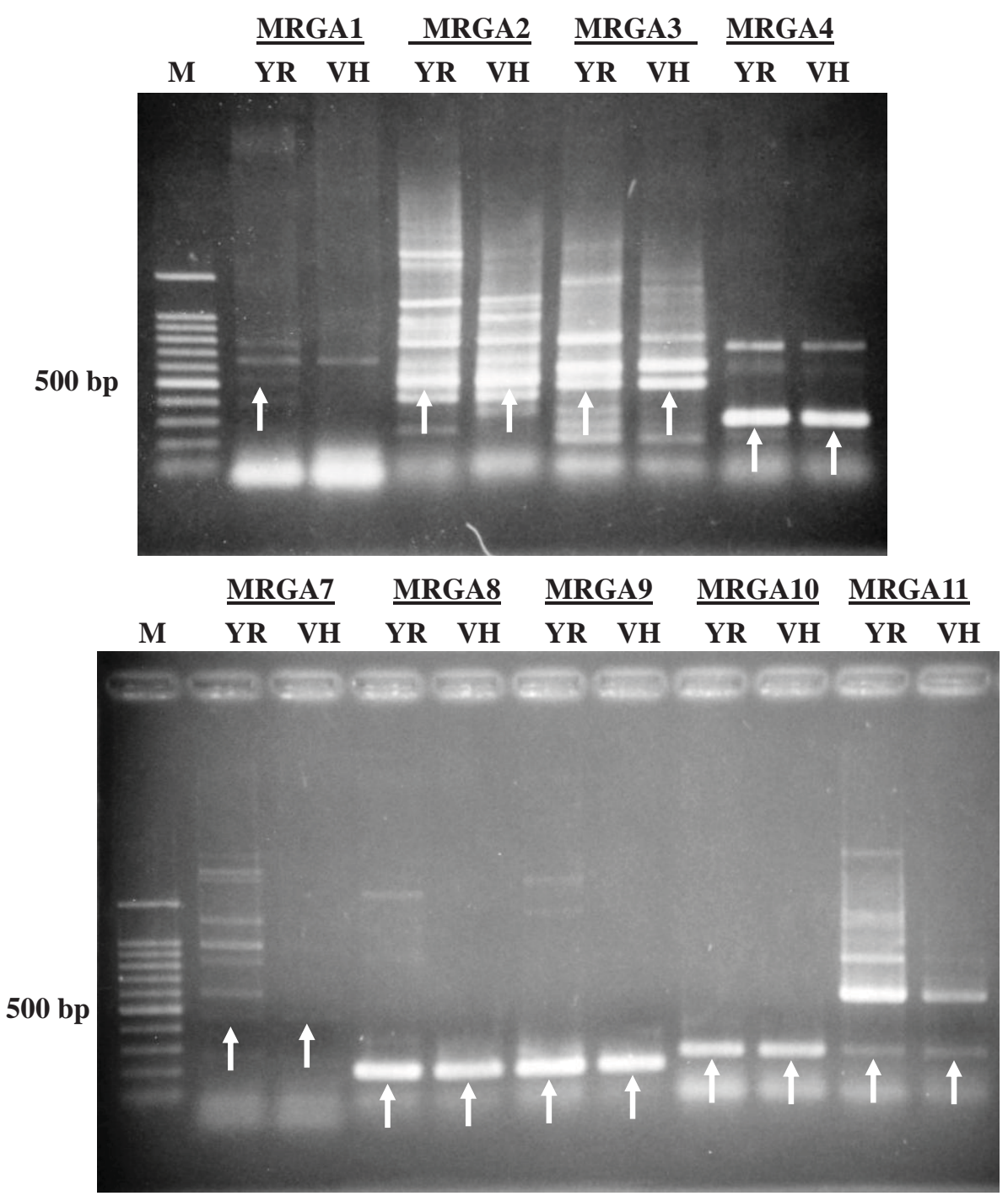

Figure 6. PCR products amplified by SCAR-MRGAs primers in cultivars Yamatouri (YR) and Vakharman (VH). MRGAs 1-4 and MRGAs 7-9 consist nucleotides-binding site and leucine-rich repeats (NBS-LRR), while MRGAs 1011 contain Toll/Interleukin-1 receptor (TIR) sequences of melon. M: 100 bp DNA ladder (Promega). Arrows indicate DNA bands showing expected mobility.

tagged sites (STSs), Monna et al. (1994). Primer sequenced used for STS were MRGA1-F: 5'TCGGCACAGCCGTTGGTGTCG-3' and MRGA1-R: 5'-CGCTCCTGTAGTATCTAC GAC-3') and used in the genetic analysis of $\mathrm{F}_{2}$ mapping population. Among $154 \mathrm{~F}_{2}$ individual plants, only 2 recombinants were detected between $\mathrm{Creb}-2$ and MRGA1, while in the remaining $152 \mathrm{~F}_{2}$ individual plants, MRGA1 co-segregated with Creb-2 (Table 6). A map distance between MRGA1 and Creb-2 was estimated to be $1.7 \mathrm{cM}$ (Figure 8).

\section{MRGA1 in diverse melon}

Some melon cultivars such as Yamatouri, Mawatauri, Miyamauri, Shinjong, and Sanuki-shirouri were reported resistance to CMV-B2 with no visible symptoms in upper leaves (Daryono et al., 2003). Furthermore, cultivars Kohimeuri, Mi Tang Ting, and PI 161375 were also reported resistance to others CMV isolates (Hirai \& Amemiya, 1989; Pflieger et al.; 1999; Speulman et al., 1998). These cultivars were tested by MRGA1 primer whether or not they maintained 


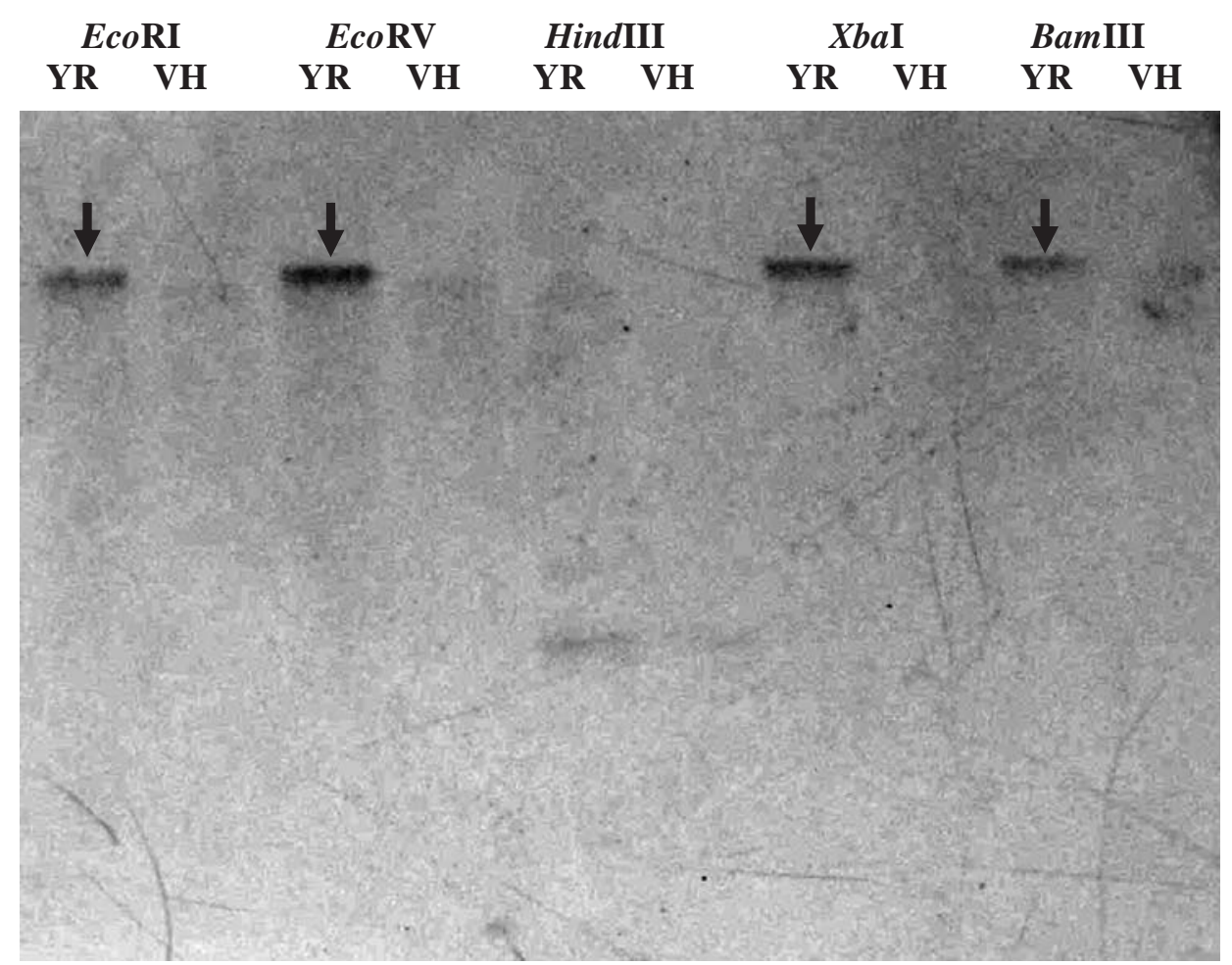

Figure 7. Southern hybridization with DNA fragments cloned from the MRGA1. The restriction endonucleases used are indicated above the lanes.

Table 6. Phenotypic frequencies of $154 \mathrm{~F}_{2}$ individual plants

\begin{tabular}{|c|c|c|c|c|c|}
\hline \multirow{2}{*}{\multicolumn{2}{|c|}{ Loci }} & \multicolumn{4}{|c|}{ Phenotypes } \\
\hline & & \multicolumn{2}{|c|}{ (Resistant $\mathrm{F}_{2}$ Individuals) } & \multicolumn{2}{|c|}{ (Susceptible $\mathrm{F}_{2}$ Individuals) } \\
\hline $\mathrm{A}$ & B & $\mathrm{r} /+^{1}$ & $\mathrm{r} /-^{1}$ & $\mathrm{~s} /+^{1}$ & $\mathrm{~s} /-^{1}$ \\
\hline Creb-2 & SCOPE14542² & 111 & 8 & 11 & 24 \\
\hline Creb-2 & SCAPB051046² & 113 & 6 & 12 & 13 \\
\hline Creb-2 & MRGA1 & 117 & 2 & 0 & 35 \\
\hline
\end{tabular}

${ }^{1}$ : Resistant and susceptible were judged by SCAR markers; ${ }^{2}$ : Daryono et al. $(2005,2010)$.

resistance gene analogous linked to Creb-2. Result showed that MRGA1 primer was amplified in cultivars Yamatouri, Mawatauri, Sanuki-shirouri, Kohimeuri, and PI 161375, except cultivars Miyamauri, Shinjong, and Mi Tang Ting. This result suggested that these cultivars did not have Creb-2 and showed to be susceptible against CMV-B2.

\section{Discussion}

Two families of 11 melon genomic fragments homologous to NBS and TIR genes were isolated using PCR-based approach with degenerate primers that targeted the conserved motifs of the NBS and TIR domain from different plant $R$ genes. The primers used in this study were designed according to Leister et al. (1996) and Brotman et al. (1998). Another primer combination (Leister et al., 1998) that had not been used for this purpose in melon and which matches the TIR domain was used to isolate another type of putative resistance genes in melon. As the results, two families include 11 MRGAs have been isolated. The first family of NBS includes 9 MRGAs, while the second family of TIR contains two MRGAs. The PCR based approach taken in this study allowed for good sampling of these $R$ genes families. 


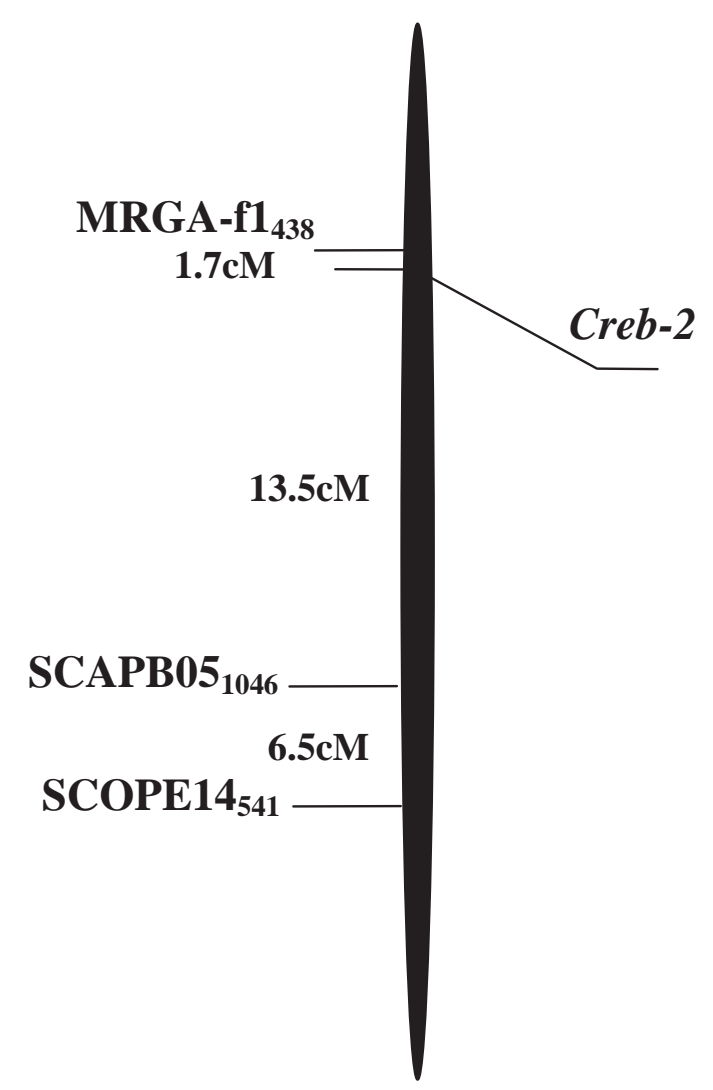

Figure 8.Linkage analysis of MRGA-f1 and SCAR markerswiththe Creb-2 locus

Furthermore, using the few conserved motifs to construct degenerate PCR primers, it has been possible to clone R-gene analogs (RGAs) from many plant species, e.g. rice and barley (Leister et al., 1996), potato (Lawrence et al., 1995), tomato (Pan et al., 2000), pepper (Parker et al., 1997), soybean (Joyeuk et al., 1999; Witham et al., 1994), common bean (Leister et al., 1998; Pitrat \& Lecoq, 1980), Arabidopsis (Song et al., 1995), lettuce (Saitou \& Nei, 1987), Brassica (Li et al., 1999), pea (Takada, 1979), and melon (Brotman et al., 1998, Garcia-Mas et al., 2001).

Cloning of melon NBS homologues proved to be a laborious task, because many cloned fragments harbored unrelated sequences, e.g. in combination V (MRGAs 12 to 15). Longer primers with fewer inosine bases, such as primer AS1 and 310 (Table 1) improved the rate of homologous. Most of clones were degenerated using primers based on the 'P-loop' and GLPL which also called Hydrophobic domain (Brotman et al., 1998), and Kinase 2. However, only two were produced by a primer based on 310 or Kinase-3.

The analysis of the NBS domains of different $R$ genes and RGAs of NBS type suggest classification into either TIR or nonTIR linked sequence (Martin et al., 1993; Pan et al., 2003). The first are characterized by the presence of an aspartic acid residue (D) at the final portion of the kinase- 2 motifs. Examples of these genes are the genes $N$ and L6. In contrast, the non-TIR sequences have a tryptophan residue $(W)$ in the same position and included RPS2, RPM1, and 12C-2 (Leister et al., 1998). Based on this criterion, MRGA3 is predicted to be non-TIR containing sequences (Figure2).

MRGAs from the NBS type in this study showed 6 to $59 \%$ amino acid identities to cloned $R$ genes and between them. This level of similarityis equivalent to that shown between cloned $R$ genes. In fact, low levels of identities are obtained when NBS sequences of the TIR type are compared with those of non-TIR type.

Using the primers designed from the converted TIR domain of the genes $N, L 6$, and RPS5, a new type of RGAs from melon (MRGA10 and MRGA11) was obtained indicating that the TIR containing $R$ genes are specific to dicotyledonous (Martin et al., 1993).

Among nine NBShomologous tested, one (MRGA1)was shown in resistant Yamatouri and absent in susceptible Vakharman. Thus, MRGA1 is to be linked to $R$ genes involved in response to CMV-B2 and the Creb-2 locus appeared to be part of $R$ genesin MRGA1.

Moreover, several hypotheses in regard to $R$ genes can be summarized; First, $R$ genes in a plant species are distributed in cluster in many locations of its genome (Crute \& Pink, 1996; Botella et al., 1997). Second, $R$ genes from different species appear to share sequence similarities in certain domains of their gene products such as leucine rich 
repeats (LRR) and nucleotide binding sites (NBS; 3). Third, different $R$ genes from a particular plant species against one of its pathogens may not show high homology in DNA sequence. Fourth, quantitative trait loci (QTL) for partial resistance tend to map at genomic regions in the vicinity of clustered R-genes (Li et al., 1999; Wang et al., 1994).

In conclusion, positional cloning of genes of agronomic interest has not been achieved yet in melon, and saturating the melon map with some MRGA genes may render the future identification of functional resistance genes much easier.

\section{Acknowledgments}

The authors would like to express special thanks to Dr. T. Ohmori, Genome Center, Utsunomiya University, Japan, for kind advices on characterization of resistance gene analogous in melon. The completion of this research study would not be realized without the support and help of the Hitachi Scholarship Foundation, Japan for providing the author the needed research grant.

\section{References}

Aatrs MGM, te Lintel Hekker B, Holub EB, Beynon JL, Stiekema WJ, \& Pereira A. 1998. Identification of R-gene homologous DNA fragment genetically linked to disease resistance loci in Arabidopsis thaliana. Mol Plant-Microbe Interact. 11:251-258.

Backer B, Zambryski P, Staskawicz B, \& Dinseh-Kumar, SP. 1997. Signaling in plant-microbe interactions. Science. 276:726-733.

Bent AF, Kunkel BN, Dahlbeck D, Brown KL, Schimdt R, Giraudat J, Leung J, \& Staskawicz BJ. 1994. RPS2 of Arabidopsis thaliana: A leucine-rich repeat class of plant disease resistance genes. Science. 265:1856-1860.

Botella MA, Coleman MJ, Hughes DE, Nishimura MT, Jones JD, \& Somerville SC. 1997. Map positions of 47 Arabidopsis sequences with sequence similarity to disease resistance genes. Plant J. 12(5):1197-211.

Brotman Y, Silberstein L, Kovalski I, Perin C, Dogimont C, Pitrat M, Klingler J, Thompson GA, Perl-Treves R, \& Dangl J. 1998. Plants just say NO to pathogens. Nature. 394: 525-527.

Crute IR, \& Pink DAC. 1996. Genetics and utilization of pathogen resistance in plants. Plant Cell. 8:1747-1755.

Dangl, J. 1998. Innate immunity: Plants just say NO to pathogens. Nature 394: 525, 527.

Daryono BS, \& Natsuaki KT. 2002. Application of random amplified polymorphic DNA markers for detection of resistant cultivars of melon (Cucumis melo L.) against cucurbit viruses. ActaHorticult. 588:321-329.

Daryono BS, Somowiyarjo S, \& Natsuaki KT. 2003. New source of resistance to Cucumber mosaic virus in melon. SABRAO J Breed Gen. 35 (1): 19-26.

Daryono, B.S., S. Somowiyarjo, \& K.T. Natsuaki. 2005. Screening for Resistance to Kyuri green motle mosaic virus in various melons. Plant breed. 124:487-590.

Daryono BS, Wakui K, \& Natsuaki KT. 2010. Linkage analysis and mapping of SCAR markers linked to CMV-B2 resistance gene in melon. SABRAO J Breed Gen. 42(1):35-45

Dixon MS, Jones DA, Keddie JS, Thomas CM, Harrison K, \& Jones JD. 1996. The tomato Cf-2 disease resistance locus comprises two functional genes encoding leucinerich repeat proteins. Cell. 84:451-459.

Flor HH. 1971. Current status of gene-forgene concept. Ann Rev Phytopathol. 9:275296.

Garcia-Mas J, van Leeuwen H, Monfort A, de VicenteMC, Puigdomenech P, \& Arus P. 2001. Cloning and mapping of resistance gene homologues in melon. Plant Sci. 161:165-172.

Geffroy V, Sicard D, de Oliveira JC, Sevignac M, Cohen S, Gepts P, Neema C, Langin T, \& Dron M. 1999. Identification of an ancestral resistance gene cluster involved 
in the coevolution process between Phaseolus vulgaris and its fungal pathogen Colletotrichum lindemuthianum. Mol PlantMicrobe Interact. 12:774-784.

Hirai S, \& Amemiya Y. 1989. Studies on the resistance of melon cultivars to cucumber mosaic virus (I) virus multiplication in leaves or mesophyll protoplasts from a susceptible and a resistant cultivars. Ann Phytopath Soc Japan. 55: 458-465.

Jones DA, Thomas CM, Hammond-Kosack KE, Balint-Kurti PJ, \& Jones JD. 1994. Isolation of the tomato Cf-9 gene for resistance to Cladosporium fulvumby transposon tagging. Science. 266:789-793.

Joyeuk A, Fortin MG, Mayerhofer R, \& Good AG. 1999. Genetic mapping of plant disease resistance gene homologues using a minimal Brassica napus L. population. Genome. 42:735-743.

Kanazin V, Marek LF, Shoemaker RC. 1996. Resistance gene analogs are conserved and clustered in soybean. ProcNatlAcadSciUSA 93: 11746-11750.

Lander ES, Green P, Abrahamson J, Barlow A, Daley MI, Lincoln SE, \& Newberg L. 1987. MAPMAKER: an interactive computer package for constructing primary genetic linkage maps of experimental and natural populations. Genomics. 1:174-181.

Lawrence GJ, Finnegan EJ, Ayliffe MA, \& Ellis JG. 1995. The L6 gene for flax rust resistance is related to the Arabidopsis bacterial resistance gene RPS2 and the tobacco viral resistance gene $N$. Plant Cell. 7:1195-1206.

Leister D, Ballvora A, Salamini F, \& Gebhardt C. 1996. A PCR-based approach for isolating pathogen resistance genes from potato with potential for wide application in plants. Nat Genet. 14:421-429.

Leister D, Kurth J, Laurie DA, Yano M, sasaki T, Devos K, Graner A, \& Schulze-Lefert P. 1998. Rapid reorganization of resistance genes homologues in cereal genomes. Proc Natl Acad Sci USA. 95: 370-375.

Li R, Mignot E, Faraco J, Kadotani H, Cantanese, J, Zhao B, Lin X, Hinton L,
Ostrander EA, Patterson DF, \& de Jong PJ. 1999. Construction and characterization of an eightfold redundant dog genomic bacterial artificial chromosome library. Genomics. 58:9-17.

Lopez CE, Acosta IF, Jara C, Pedraza F, Gaitan-Solis E, Gallego G, Beebe S, \& Tohme J. 2003. Identifying resistance gene analogs associated with resistances to different pathogens in common bean. Phytopathology. 93:88-95.

Martin GB, Brommonschenkel SH, Chunwongse J, Frary A, Ganal MW, Spivey R, Wu T, Earle ED, \& Tanksley SD. 1993. Map-based cloning of a protein kinase gene conferring disease resistance in tomato. Science. 262: 1432-1436.

Meyers BC, Dickerman AW, Michelmore RW, Sivaramakrishnan S, Sobral BW, \& Young ND. 1999. Plant disease resistance genes encode members of an ancient and diverse protein family within the nucleotide-binding superfamily. Plant J. 20:317-332.

Michelmore RW, \& Meyer BC. 1998. Cluster of resistance genes in plants evolve by divergent selection and birth-and-death process. Genome Res. 8(11): 113-1130.

Mindrinos M, Katagiri F, Yu GL, \& Ausubel FM. 1994. The A. thaliana disease resistance gene RPS2 encodes a protein containing a nucleotide-binding site and leucine-rich repeats. Cell. 78:1089-1099.

Monna L, Miyao A, Inoue T, Fukuoka S, \& Yamazaki M. 1994. Determination of RAPD markers in rice and their conversion into sequence tagged sites (STSs) and STSspecific primers. DNA Res. 1: 139-148.

Nelson RR. 1972. Stabilizing racial populations of plant pathogens by use of resistance genes. J Environ Qual. 1(3):220-227.

Pan QL, Liu YS, Budai-Hadrian O, Sela M, Carmel-Goren L, Zamir D, \& Fluhr R. 2000b. Comparative genetics of nucleotide binding site-leucine rich repeat resistance gene homologues in the genomes of two dicotyledons: tomato and Arabidopsis. Genetics. 155:309-322. 
Pan QL, Wendel J, \& Fluhr R. 2000a. Divergent evolution of plant NBS-LRR resistance gene homologues in dicot and cereal genomes. J. Mol. Evol. 50:203-213.

Parker JE, Coleman MJ, Szabo V, Frost L N, Schmidt R, van der Biezen EA, Moores T, Dean C, Daniels MJ, \& Jones JD. 1997. The Arabidopsis downy mildew resistance gene RPS5 shares similarity to the toll and interleukin-1 receptors with $\mathrm{N}$ and L6. Plant Cell. 9: 876-894.

Pflieger S, Lefebvre V, Caranta C, Blattes A, Goffinet B, \& Palloix A. 1999. Disease resistance gene analogs as candidates for QTLs involved in pepper-pathogen interactions. Genome. 42:1100-1110.

Pitrat M, \& Lecoq H. 1980. Inheritance of resistance to cucumber mosaic virus transmission by Aphis gossypii in Cucumis melo. Phytopatology. 70:958-961.

Rivkin MI, Vallejos CE, \& McClean PE. 1999. Disease resistance related sequences in common bean. Genome 42: 41-47.

Saitou N, \& Nei M. 1987. The neighborjoining method: A new method for reconstructing phylogenetic trees. Mol. Biol. Evol. 4: 406-425

Shen KA, Meyers, BC, Islam-Faridi MN, Chin DB, Stelly DM, \& Michelmore RW. 1998. Resistance gene candidates identified by PCR with degenerate oligonucleotide primers map to clusters of resistance genes in lettuce. MolPlant-Microbe Interact. 11:815-823.

Song WY, Wang GL, Chen LL, Kim HS, Pi LY, Holsten T, Gradner J, Wang B, Zhai WX, Zhu LH, Fauquet C, \& Ronald PC. 1995. A receptor kinase-like protein encoded by the rice disease resistance gene, $\mathrm{Xa} 21$. Science. 270:1804-1806.

Speulman E, BouchezD, Holub EB, \& Beynon JL. 1998. Disease resistance gene homologs correlate with disease resistance loci of Arabidopsis thaliana. Plant J. 14:467-474.

Takada K. 1979. Studies on the breeding of melon resistant to cucumber mosaic virus. III. Inheritance of resistance of melon to cucumber mosaic virus and other characteristics. Bull Veg Ornam Crops Res. A5:71-79.

Thomas CM, Jones DA, Parniske M, Harrison K, Balint-Kurti PJ, Hatzixanthis K, \& Jones JD. 1997. Characterization of the Tomato $C f-4$ gene for resistance Cladosporium fulvum identifies sequences that determine recognitional specificity in Cf-4 and Cf-9. Plant Cell. 9:2209-2224.

Thomphson JD, Higgins DG, \& Gibson TJ. 1994. CLUWTAL W: Improving the sensitivity of progressive multiple sequence alignment through sequencing weighting, position specific gap penalties and weight matrix choice. Nucleic Acids Res. 22: 4673-4680

Timmerman-Vaughan GM, Frew TJ, \& Weeden NF. 2000. Charaterization and linkage mapping of R-gene analogous DNA sequencing in pea (Pisum sativum L.). TheorAppl Gen. 101:241-247.

Wang M, Champion LE, Biessmann H, \& Mason JM.1994. Mapping a mutator, mu2, which increases the frequency of terminal deletions in Drosophila melanogaster. Mol Gen Genet. 245(5): 598--607.

Witham S, Dinesh-Kumar SP, Choi D, Hehl R, Corr C, \& Baker B. 1994. The product of the tobacco mosaic virus resistance gene N: Similarity to toll and interleukin-1 receptor. Cell. 78:1101-1115.

Yu YG, Buss GR, \& Maroof MA. 1996. Isolation of a superfamily of candidate disease-resistance genes in soybean based on a conserved nucleotide-binding site. Proc Natl Acad Sci USA. 93: 11751-11756. 